\title{
Kembang Endhog Arts Study and Creation in the Mauludan Tradition in Banyuwangi
}

\author{
Henny Rahma Dwiyanti ${ }^{1, *}$, I Ketut Sunarya ${ }^{2, * *}$ \\ ${ }^{1}$ Arts Education Graduate Program, Yogyakarta State University, Depok 55281, Yogyakarta, Indonesia \\ ${ }^{2}$ Department of Fine Arts Education, Yogyakarta State University, Depok 55281, Yogyakarta, Indonesia \\ *Corresponding author.Email: hennyrahmadwiyanti@gmail.com \\ ${ }^{* *}$ Corresponding author. Email: iketutsunarya@ rocketmail.com
}

\begin{abstract}
Kembang Endhog tradition is a hereditary tradition of the Osing community in Banyuwangi. This tradition, usually called the Mauludan tradition, is celebrated on the 12th of Rabiul Awal every year to commemorate the birth of the Prophet Muhammad, called Mauludan. The purpose of this research is to find out the meaning of the unique Mauludan Tradition in Banyuwangi and also to know the forms of the Kembang Endhog which is visualized in the form of eggs which are decorated in such a way. This research uses descriptive qualitative research using data collection methods by interview, observation and direct observation. The results of this study are that the Mauludan celebration in Banyuwangi has not changed until now, it still uses customary methods for generations, namely using Kembang Endhog as a visualization whose meaning is symbolizing a birth, mutual cooperation, cooperation and gratitude have been given life by Allah S.W.T. Visually, the form of the Kembang Endhog presented usually follows the development of the era with unique and beautiful forms, so that people can be more interested in being able to participate, watch and be involved in it.
\end{abstract}

Keywords: Mauludan Tradition, Kembang Endhog Arts, Osing Community

\section{INTRODUCTION}

Banyuwangi is one of the regencies or cities in the East Java Province in the island of Java. It is located at the eastern end of the island, bordered by the Province of Bali. In addition to a number of other tribes such as the Javanese, Madurese, and Balinese, the majority of Banyuwangi inhabitants are in fact the Osing people, the native tribe of the region.

Naturally, Osing language is the main vernacular language used in the region for day-to-day communication. Most of the Banyuwangi people are Muslims, while others have different religions including Christian, Catholic, Hindu, and Buddhism. The cultural tradition and customs of Banyuwangi have a distinct characteristic from other regions as they often combine religious ceremonies and traditional art forms.

The history of Islamic dissemination by Wali Songo, as well as the diverse ethnic groups in Banyuwangi have influenced the customs, daily life, traditions, culture, and art forms in the region, especially as they bring different languages and cultures.

Some of the popular traditional art forms in Banyuwangi include traditional dance, sculptures, carpentries, batik, and kendang kempul. These forms of art and culture are typically associated with religious ceremonies, especially the Islamic religious celebrations as the major religion in the region. Islamic holidays and occasions in Banyuwangi are continuously preserved and celebrated with local culture in this modern age. In other words, this kind of culture has become an inseparable part of the modern society in the region.

According to Panghoeloe, human and culture are one strong unity that is impossible to separate from one another. Culture exists as the result of the work of humans [1].

The development of traditional culture and art in society is generated from the system of continuous cultural inheritance from generation to generation. Tradition is a custom that is regularly done for particular purposes in relation to the local culture and customs. Some traditions are purely born from the community, while others are influenced by the people's religious behaviours. The mauludan Islamic tradition is a good instance of the latter.

Islam spread in Java with the help of a group of Islamic scholars who are popular as Wali Songo, who promotes the teachings of the religion with compassion instead of violence. These wali incorporates the values and teaching of Islam in the local communities' tradition in a respectful way, and managed to not entirely abandon the original tradition. Naturally, the people of Java, who are known to be the proudest of their tradition of offerings, gamelan, and gathering (selamatan) respond well to this approach. 
Sutiyono points out that the use of tradition for dakwah (preaching of Islam) purposes is a subtle approach of dakwah. The wali smartly incorporate Islamic values in the cultural traditions through symbols. This is why other Islamic scholars consider Wali Songo's dakwah style as very subtle [2].

In regard to traditional arts, the mauludan celebration which commemorates the birth of the Prophet Muhammad can be considered as one of the religious traditions that successfully integrates into the culture and tradition of the local community in Banyuwangi.

The art forms involved in the mauludan tradition include crafts and music. The crafts-making aspect is evident through the detailed decoration of the eggs, while the music is represented by the traditional folk music of patrol, which includes kentongan (traditional bamboo slit drum) and traditional bamboo flute, as well as the recitation of salawat (praises for the Prophet Muhammad).

Tradition is understood as the customs that are passed across generations. It is typically held every year and often regarded not only as a form of gratitude toward God Almighty but also serves to defy bad luck and prevent bad things from happening.

This is line with Sutiyono's statement on how the village community consistently manifests their expression of gratitude annually, as opposed to merely in sayings [3]. In contrast, in the reformation era today, most government officials or representatives are prone to lip service, not having to worry about how they would deliver their promises in reality.

The development of traditional culture and art in society is generated from the system of continuous cultural inheritance from generation to generation. Tradition is a custom that is regularly done for particular purposes in relation to the local culture and customs. In his book Culture and Society, Kuntowijoyo points out that traditional culture no longer serves as a symbol for social status, as anyone who can raise their economic, social, and intellectual status may be a part of the high culture [4].

Art is closely related to culture. In the community life, art and culture develops based on the demands and needs of the society. Each community generates a distinct form a culture based on what the community needs and responds to. In the tradition of kembang endhog, the following questions rise as the main points of the research: what is the significance and meaning of the procession? What are the forms of kembang endhog visualizations? This study attempts to address these questions.

\section{METHOD}

This study is a descriptive qualitative research. The descriptive qualitative research method focuses on indepth observations in addition to interviews as well as direct interactions with cultural practitioners when the event takes place. The researcher looks for evidences in the field based on the problem formulation, then takes notes and collects the data to ultimately draw conclusions. According to Denzin and Yvonne, qualitative studies put emphasis on social construct, the relation and closeness between the researcher and the object observed, as well as situational events that sharpen the research [5]. The search for answer to the research questions relies on how a social experience is developed and gives meaning.

Based on those regards, this research has addressed the notion of a qualitative descriptive research by conducting a direct observation on the whole procession of the traditional event, from the making and arrangement of kembang endhog decorations to the end of the celebration at the mosque where the people gather and dine together.

\section{RESULTS AND DISCUSSION}

The findings of the observation, interviews, and direct observation suggest that the mauludan tradition has been around for quite some time, with no exact date of the initiation. It is simply known that on the day of birth of the Prophet Muhammad SAW, celebration must be held with kembang endhog as the central point and symbol to be paraded around the village while reciting the salawat and ended with enjoying the food together in the village mosque. The procession occurs similarly every year. The only difference is in the creativity in decorating kembang endhog which has evolved throughout the years.

From the perspective of art, there are interesting aspects in the mauludan tradition which intrigues the researchers to study what, why, and how such tradition comes to be. The tradition is visualized with the eggs as the main symbol of mauludan. The procession begins with boiling chicken or duck eggs until they are hard-boiled, then decorating the eggs with small ornaments made of paper, plastic, bamboo, or others with a small bamboo pick stuck in the eggs so that they can be attached to the jodhang. The flower-shaped ornaments have typically been prepared days prior to the celebration, either handmade or bought from the seasonal crafters at the market. 


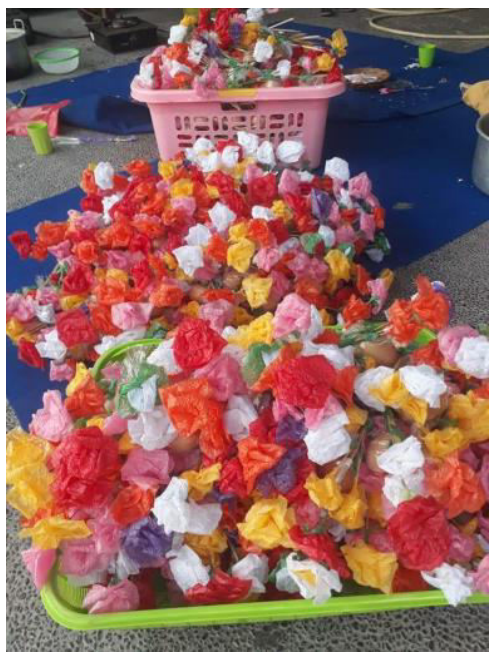

Figure 1 Some of the kembang endhog decorations prior to being arranged on the jodhang

As people's creativity in creating decorations advances throughout the years, today, the egg decorations are not only in the form of flowers but also other forms, such as barongs, snakes, animals, birds, and other popular forms. Some kembang endhog decorations even do not use bamboo picks to help making them stick to the jodhang, as they can just be wrapped with plastic. It is indeed a curious thing to notice that the decorations are not in the shape of a flower, considering there is literally kembang or "flower" in the phrase kembang endhog. Nevertheless, the name to call the egg ornament in this tradition has stuck among the local community for ages.

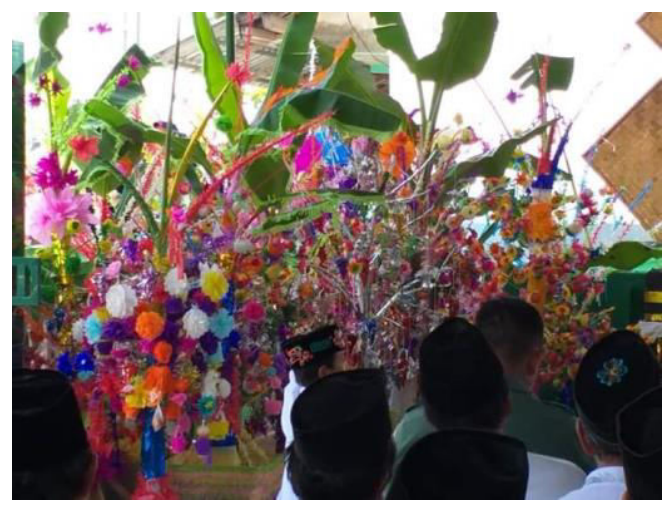

Figure 2 Kembang endhog parade

Traditionally, kembang endhog decorations are made with a small bamboo pick to which colourful flower paper or plastic ornaments in various shapes are attached. The variety of shapes must still conform to the flower-shape as kembang endhog literally means "egg flower." Therefore, the ornaments are expected to take various shapes of flower. However, this study found that the creations of kembang endhog have continuously evolved throughout the years. The variety of shapes do not remove the significance of meaning of kembang endhog as the main element in the mauludan tradition.
A Muslim family typically prepares kembang endhog based on their capacity. Some prepares four to five, or even more. These decorative ornaments are then collected with those prepared by other families in the community. In addition to kembang endhog, each family also prepares rice with side dish in a plastic or bamboo tray to be enjoyed together in the celebration.

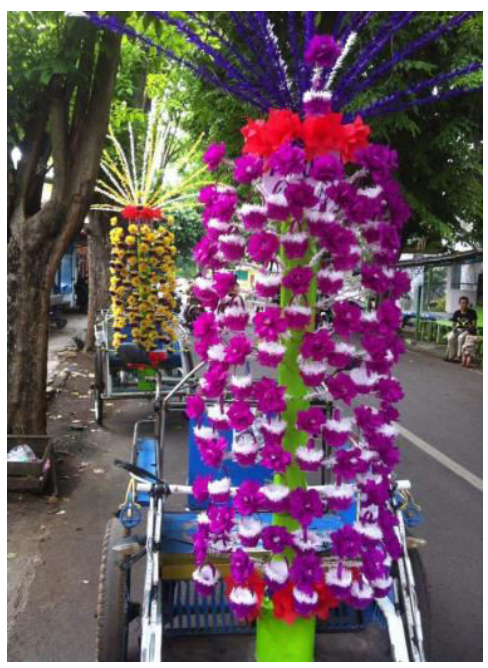

Figure 3 Kembang endhog paraded around using a pedicab (becak)

The bunch of decorated kembang endhog are then attached to several jodhang or banana tree trunks. The jodhang are then paraded around the village using simple vehicles such as bicycles and pedicabs. Some do it on foot, while others use a pick-up truck to carry a large jodhang. The whole parade is serenaded by salawat recitation and the patrol traditional music, as well as rebana that are amplified using a sound system that is rented exactly for this purpose. The parade will stop at the village mosque. After that, the kembang endhog is taken to the inside of the mosque, and the elder Islamic leaders will pray together. The celebration ends with enjoying a meal together in a bamboo tray.

The observation and interview with the local residents suggest that the use of egg as a part of the mauludan celebration is founded on the belief that egg symbolizes birth. Meanwhile, the jodhang that the eggs are attached to is considered to be a lifelong tree of the tree of life. The communal celebration of the villagers that parade around the village, ended with dining together, represents kinship, togetherness, cooperation, and collaboration between community members. 
The egg decorations are considered as a form of respect and love toward the Prophet Muhammad SAW. For the Muslim people, the Prophet Muhammad is a representation of good. In this sense, the more beautiful and creative the kembang endhog decorations, the higher their value. The jodhang serves as a symbol of the tree of life or the lifelong tree. The communal celebration of the villagers that parade around the village, ended with dining together, represents kinship, togetherness, cooperation, and collaboration between community members.

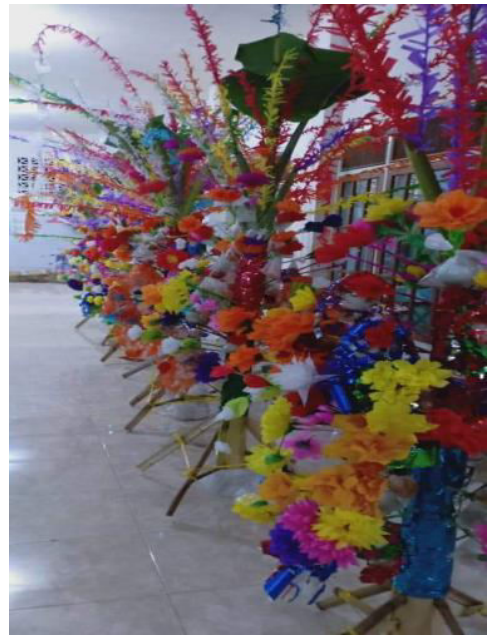

Figure 4 Kembang endhog placed inside the mosque after the parade

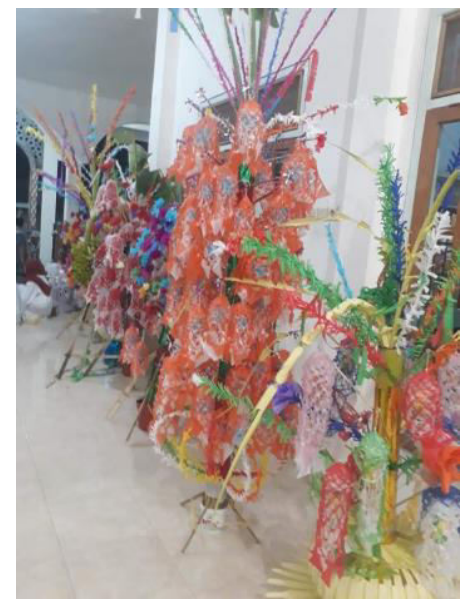

Figure 5 The styles of kembang endhog after the parade

Although the modern culture is currently dominating this era, the spirit of the local community in celebrating their mauludan tradition every year does not decrease. Only few elements experience a change, namely in the shapes and style of kembang endhog decorations which evolve from time to time as they follow the current trend or what is popular at the time. This transformation of shape does not reduce the value, but instead affects the competitiveness among the craft makers in the traditional market in the mauludan season. It is common for kembang endhog decorations to be sold at the market as not everyone makes them at home. For the sellers, it is important to create and try to be as creative as possible in order to attract the buyers. The more unique the design, style or shape, the more people will buy. The traditional shape of kembang endhog is the flower, but nowadays, there are many other different shapes people can find in the market, such as the barong, the bird, and other objects.

From the local community's perspective, the birthday celebration of the Prophet Muhammad with pretty decorations is their way of showing love and respect toward the Prophet as the role model of the Muslim people. Therefore, this tradition is preserved and improved in certain aspects, such as in the visualization of the kembang endhog shapes and styles. The better-looking and more creative the kembang endhog decoration, the higher its value will be.

\section{CONCLUSION}

The following conclusions are drawn based on the findings of this study.

- The kembang endhog mauludan tradition has a symbolic meaning, in which the egg (endhog) represents birth, while the egg placement on the jodhang symbolizes the tree of life. The dining together at the end of the parade represents harmony, togetherness, mutual cooperation and kinship among the people in the community.

- In terms of creativity, the craftspeople making the kembang endhog decorations must be able to keep up with the times every year in order to produce more interesting styles. The more interesting or unique it is, the more pride the people in the community have on the celebration as they can present something that is special and one of a kind.

- It is instrumental that the kembang endhog craft makers have good information literacy and technology literacy in order to keep up with the development of the variety of kembang endhog creations by looking into the current popular trends. 


\section{REFERENCES}

[1] Manggis, M. Rasjid, and Dt Radjo Panghoeloe. Minangkabau: sejarah ringkas dan adatnya [Minangkabau: concise history and customs]. Penerbit Mutiara, 1982. p. 28.

[2] Sutiyono, Dr. Poros Kebudayaan Jawa [Axis of Javanese Culture]. Graha Ilmu, 2013. p. 129.

[3] Sutiyono, Dr. Poros Kebudayaan Jawa [Axis of Javanese Culture]. Graha Ilmu, 2013. p. 65.

[4] Kuntowijoyo. Budaya dan Masyarakat [Culture and Society]. Tiara Wacana Yogya, 2006. p. 37.

[5] Pradoko, A. M. Paradigma-Paradigma Kualitatif untuk Pengkajian Seni, Humaniora dan Budaya [Qualitative Paradigms for the Study of Art, Humanities and Culture]. UNY Press, 2017. p. 5. 